\title{
Reconstruct English Teaching against the Background of MOOCs Based on an Empirical Study Of "Oral English 2" Teaching Reform
}

\author{
Huijuan Xue \\ Humanities and Management \\ Jiangxi Police Institute \\ Nanchang, China \\ xuehuijuan1@yahoo.com
}

\begin{abstract}
Based on the empirical data elicited from "Oral English 2" teaching reform and the specially-designed questionnaire, with freshmen as the subject, this paper researches on how to reconstruct oral English teaching in terms of content, method and assessment against the background of MOOCs. The conclusions are as follows: 1) the course reform has improved the students' competence of making PPT presentation, especially the abilities to search literature, screen and synthesize online learning resources, 2) it has improved the students' oral communicative competence in English, and 3) it has developed students' autonomous learning skills and critical thinking and problem-solving abilities, thus achieving the desired results.
\end{abstract}

Keywords-oral English teaching, course reform, assessment, blended-learning, oral communicative competence

\section{INTRODUCTION}

In the new century, multimedia technology, digitization, big data and mobile Internet are developing rapidly; digital courses, network platform, online learning and other forms are constantly impacting the traditional English teaching. Classroom teaching and extracurricular learning, online and offline, paper teaching materials and digital information and artificial intelligence and so on witness the integration in the development trend. English teaching in Chinese higher education has undergone profound changes from content to method and assessment. In order to meet the urgent requirements of teaching innovation in the rapidly changing Internet era, this paper makes an empirical study of the teaching reform of "Oral English 2" (OE2) and focuses on how to reconstruct spoken English teaching against the background of MOOCs.

\section{LITERATURE REVIEW: ORAL ENGLISH TEACHING AND COMMUNICATIVE COMPETENCE DEVELOPMENT}

With the popularization of "communicative approach" in the 1970s, the focus of developing English learners has shifted from linguistic competence to communicative competence. Furthermore, the "Flipped Classroom" in the new century has transferred the power of decision to learn from teachers to students. In today's information age, "face-to-face + on/offline" blended learning mode has swept across the education sector in China, and more educators are beginning to practice "Flipped Classroom", "MOOCs" and mixed learning style of English teaching and study its impact. Based on the Input Hypothesis Model of second language (L2) learning and production by Krashen [1], revealing comprehensible input $\rightarrow$ affective filter $\rightarrow$ language acquisition device $\rightarrow$ acquired knowledge $\rightarrow$ output, Wang designed oral English teaching as: a) before class: create listening and speaking expectation; b) content input: provide comprehensible new linguistic information; c) test and assessment: check understanding, store linguistic information; d) language output: deepen acquisition, thus transition from understanding to flexible application [2]. She believes that applying L2 acquisition theory in oral English teaching can develop students' communicative competence better. Xue analyzes how to design various teacher-student and student-student interactions through "warm-up preparations", "unit teaching" and "after-school practice" in order to stimulate students' interest in learning English and to improve teaching effect, especially to enhance students' oral communicative competence [3].

$\mathrm{Xu}$ found that integrating English speech into the evaluation system of postgraduates' oral proficiency test can not only arouse students' attention to speaking skills but also promote the application of internalized knowledge [4]. In order to enhance the weak English-speaking capabilities in college students caused by more emphasis on input than output, English teachers has begun to use interesting English movie and video clips as auxiliary materials in oral English teaching. Students are expected to improve their oral expressive abilities by learning native-speakers' way of thinking, behavior and social customs directly. Based on empirical data, Xue found that American TV drama is more suitable to be used as auxiliary materials in teaching oral English [5]. Wang explored how to set up an online learning platform for university students [6]. He pointed out such a platform can change the traditional learning model, namely changing from the model of "being forced to learn" to "autonomy", thus enhance the learning effect. Yang studied the educational function of WeChat public platform and tried to set up the blended learning mode of "before class, in class, after class" model [7]. Yang concluded that blended learning on such a platform can stimulate learning initiative and enthusiasm, thus effectively promote students' learning. Xue explored the correlation 
between blended learning and oral English communicative competence [8]. Her empirical study showed the mixed "online and offline” learning mode improved students' classroom participation, enhanced their abilities to make PPT presentations, English thinking, oral expressive and communicative competence, and significantly improved the quality of oral teaching.

\section{RESEARCH DESIGN}

In order to meet the new teaching requirements in the information age, aiming at solving the practical teaching problems that experts put forward during the undergraduate teaching assessment in 2017, this study takes "having vitality in class and driving force after class" as the starting point. The current paper, based on OE2 as an empirical study, reconstructs teaching in the aspects of teaching content, method and assessment. This course is intended for 45 English majors (freshmen, Term 2; see Table I). To understand and evaluate the teaching effectiveness, the author designed a questionnaire, which was completed at the end of the term. The interviewees had almost no length difference in learning English in junior and senior middle-school before coming to the institute, that is, three years in each stage, but the English-learning time in primary school varied between city and country. Individual students from rural primary school only learned 1-2 years, or even did not learn any English, and most students did 4 years or more. In addition, 8 students had extra learning hours after class, including 1 had remedial classes for 4 years, 3 for 3 years, 2 for 1 and 2 years respectively.

TABLE I. SUBJECTS' BASIC INFORMATION

\begin{tabular}{|c|c|c|c|}
\hline No. & $\begin{array}{c}\text { Average English Scores at } \\
\text { Entrance Exam (\%) }\end{array}$ & $\begin{array}{c}\text { End-term Results } \\
\text { for OE1 (\%) }\end{array}$ & $\begin{array}{c}\text { End-term Results } \\
\text { for OE2 (\%) }\end{array}$ \\
\hline 45 & 76.8 & 83.7 & 84.5 \\
\hline
\end{tabular}

The questionnaire includes 32 multiple-choice questions and 3 open-ended ones. The first part of the former (8 questions) is designed to understand the subjects' views on learning English and their self-assessment of basic learning skills (see Tables II \& III). The second part consists of 23 questions using Likert scale, divided into two parts. Six questions are about the students' general English learning situation at ordinary times and the remaining ones focus on "the influence of blended learning mode on English learning and oral communicative competence" and "PPT presentation", 1-5 points for "totally disagreeing”, “disagreeing”, "basic consent”, “consent” to "full consent". The last 3 open-ended questions require students to write out the best way to improve their oral English communicative competence, the greatest benefits from the teaching reform and what they suggest to add to the online resources. This paper will use the empirical data obtained from the questionnaire to evaluate the effectiveness of the reconstructed oral English teaching against MOOCs.

Empirical data shows that the respondents are interested in learning English and fully understand the importance of "speaking", but they do not actively participate or speak out (see Table II). Their self-assessment of oral communicative competence is not satisfactory, 2 out of 5. Among the various linguistic skills of "listening” (LS), "speaking” (SP), "reading” (RD), “writing” (WR), "translation” (TR), “vocabulary” (VOC) and "grammar" (GR), 53.3\% of the respondents prefer "reading" and consider themselves the strongest in this area (48.9\%; see Table III). 44.4\% dislike "grammar" most and $42.2 \%$ view "grammar" as their weakest area. Although nearly $1 / 4$ like "speaking" the most, $24.4 \%$ consider themselves to be the weakest in "speaking", second only to "grammar".

TABLE II. A SUMMARY OF SUBJECTS’ VIEWS ABOUT ENGLISH LEARNING

\begin{tabular}{|c|c|c|c|c|c|c|c|}
\hline \multicolumn{2}{|c|}{$\begin{array}{c}\text { Interest in learning } \\
\text { spoken English }\end{array}$} & \multicolumn{3}{|c|}{$\begin{array}{c}\text { Self-assessing the } \\
\text { importance of "speaking" }\end{array}$} & \multicolumn{3}{|c|}{$\begin{array}{r}\text { Self-assessing the importan } \\
\text { communicative compe }\end{array}$} \\
\hline \multicolumn{2}{|c|}{4} & \multicolumn{3}{|c|}{4.5} & \multicolumn{3}{|c|}{\begin{tabular}{|c|}
4.4 \\
\end{tabular}} \\
\hline \multicolumn{2}{|c|}{ TABLE III. } & \multicolumn{6}{|c|}{$\begin{array}{l}\text { SUBJECTS’ SELF-ASSESSMENT OF ENGLISH LINGUISTIC } \\
\text { SKILLS }\end{array}$} \\
\hline & $\begin{array}{l}\text { LS } \\
(\%)\end{array}$ & $\begin{array}{l}\text { SP } \\
(\%)\end{array}$ & $\begin{array}{l}\text { RD } \\
(\%)\end{array}$ & $\begin{array}{l}\text { WR } \\
(\%)\end{array}$ & $\begin{array}{l}\text { TR } \\
(\%)\end{array}$ & $\begin{array}{l}\text { VOC } \\
(\%)\end{array}$ & $\begin{array}{l}\text { GR } \\
(\%)\end{array}$ \\
\hline $\begin{array}{l}\text { Like } \\
\text { Most }\end{array}$ & 6.7 & 22.2 & 53.3 & 8.9 & 2.2 & 4.4 & 2.2 \\
\hline $\begin{array}{c}\text { Dislike } \\
\text { Most }\end{array}$ & 6.7 & 15.5 & 0 & 6.7 & 15.5 & 11.1 & 44.4 \\
\hline Strongest & 6.7 & 4.4 & 48.9 & 24.4 & 0 & 13.3 & 2.2 \\
\hline Weakest & 11.1 & 24.4 & 0 & 4.4 & 8.9 & 8.9 & 42.2 \\
\hline
\end{tabular}

\section{RECONSTRUCT ENGLISH TEACHING AGAINST THE BACKGROUND OF MOOCS: AN EMPIRICAL STUDY}

\section{A. The Reform of Teaching Content}

OE2 is a compulsory course for Level-1 English majors in the second term, with emphasis on practice as its characteristics, namely, teaching and practice taking half the time respectively. The purpose of teaching is to cultivate and improve students' oral expressive and communicative competence through oral

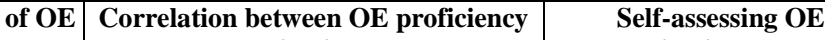

\begin{tabular}{|c|c|c|}
\hline & and communicative competence & communicative competence \\
\hline
\end{tabular}
practice gradually. At the same time, it aims at enriching students' cultural knowledge of English-speaking countries. Through taking this module, students can not only master the linguistic skills for fluent communication on everyday life and social topics, but also develop the capabilities of independent thinking. The content reform is mainly shown in the following four areas: 1) students were required to learn to search, screen and make comprehensive use of network learning resources (including audio and video clips), and to practice making PPT and giving oral presentations in English in group. 2) A "Knowledge and Practice Cup" English Speech Contest was organized, aiming at providing the students with more practice opportunities and developing their applied English abilities and oral communicative competence. 3) In addition, students (43, 95.6\%) took the test of "Language Service Competence Assessment and Training" as required, run by the China Translation Association. This was done in the purpose of meeting the new requirements of cultivating the practical and service capabilities in English language learners in the new era. 4) The reform also introduced the "English Test for 
International Communication", which laid a foundation for students to prepare for it in future.

\section{B. The Reform of Teaching Method}

OE2 mainly adopts the Communicative Approach and Situational Teaching Method. In order to reconstruct oral English teaching, the reform of teaching methods takes the cultivation of students' oral communicative competence as the starting point, highlighting the concept of "students as the main focus and teachers as the facilitating force". It combines the traditional textbooks with the rich online audio and video clips of excellent English speaking contests, film episodes and other multimedia teaching resources (uploaded on the course website and open), carries out various classroom practical activities including personal narration / presentation, recitation, dubbing, dialogue, group discussion, role play, PPT presentation and such like to help students understand the content of each unit and consolidate the language points and knowledge. In short, OE2 teaching reform is mainly embodied in the use of multimedia network teaching (online and offline), that is, the practice of "Flipped Classroom", featuring heuristic and practical characteristics in the teaching.

\section{The Reform of Assessment}

Different from the past assessment form of "reading articles + answering questions", OE2 teaching reformed evaluation methods and raised the formative assessment ratio to 50\%. In other words, the ratio of ordinary performance (formative) and final test (summative) is 50: 50\% (see Tables IV \& V).

TABLE IV. SUMMARY OF ASSESSMENT COMPONENTS IN THE COURSE

\begin{tabular}{|c|c|c|c|c|}
\hline \multicolumn{3}{|c|}{$\begin{array}{c}\text { Ordinary Performance } \\
(50 \%) \\
\end{array}$} & \multicolumn{2}{|c|}{$\begin{array}{c}\text { End-term Oral Test } \\
(50 \%) \\
\end{array}$} \\
\hline $\begin{array}{c}\text { On-line } \\
(40 \%)\end{array}$ & & $\begin{array}{c}\text { Off-line } \\
(60 \%)\end{array}$ & PPT Preparation & Oral Presentation in English \\
\hline $\begin{array}{l}\text { Watch/Listen to Video and Audio Clips (25\%) } \\
\text { (23 Tasks) }\end{array}$ & No. of Visit to the Site (15\%) & See Table V & $40 \%$ & $60 \%$ \\
\hline
\end{tabular}

TABLE V. SUMMARY OF OFF-LINE SCORES

\begin{tabular}{|c|c|c|c|c|c|}
\hline $\begin{array}{c}\text { PPT } \\
(60 \%)\end{array}$ & \multicolumn{2}{|c|}{$\begin{array}{c}\text { LSCAT } \\
(10 \%) \\
\end{array}$} & \multicolumn{2}{|c|}{$\begin{array}{c}\text { English Speech Contest } \\
(\mathbf{1 0 \% )})\end{array}$} & \multirow[t]{2}{*}{$\begin{array}{c}\text { Class Attendance } \\
(20 \%) \\
\end{array}$} \\
\hline $\begin{array}{c}\text { PPT Preparation + Group Presentation in } \\
\text { OE }(60 \%)\end{array}$ & $\begin{array}{c}\text { Participation } \\
(6 \%)\end{array}$ & $\begin{array}{l}\text { Pass } \\
(4 \%)\end{array}$ & $\begin{array}{c}\text { Participation } \\
(6 \%)\end{array}$ & $\begin{array}{r}\text { Prize-Wi } \\
(4 \%) \\
\end{array}$ & \\
\hline
\end{tabular}

“Ordinary performance” consists of two parts: "online” and "offline". The former includes the completion of watching / listening to video / audio clips (23 tasks) and the number of visits to tasks and the latter mainly refers to the preparation of PPT (electronic \& paper versions + group presentations and team work), individual classroom performance and participation in speaking, attendance, LSCAT, "Knowledge and Practice Cup" English Speech Contest. The final oral test requires students to prepare PPT presentation on 3 topics from among the 5 given themes learnt, and randomly draw questions and take oral test by speaking on the spot for about 3 minutes. The completion of PPT accounts for $40 \%$ and oral presentation takes $60 \%$. The criteria for the final test are as below: 1 . PPT preparation (including vocabulary, collocation, usage, grammar, typesetting, the style and format, etc.) 2. English linguistic skills (pronunciation, intonation, speed, language sense, fluency, coherence, consistency, mastery of subject knowledge, accuracy in answering questions, etc.) and others (such as ease and naturalness).

\section{Course Reform Effect}

Through organizing various classroom teaching activities, innovating assessment methods (adjusting the ratio of formative scores and avoiding the disadvantage of setting the tune with one beat based on a summative test) and enriching second-class language practices (such as English speech contest, LSCAT, etc.), OE2 has mobilized the students' initiatives in learning English, cultivated their learning autonomy and improved their English application abilities and oral communicative competence. After the classroom teaching reform, OE2 integrates traditional textbooks, teaching materials, audio and video clips, wonderful film episodes, excellent English speech contests, online interaction and such like. In this way, OE2 has become students' favorite comprehensive English-learning online course thanks to its richer content and livelier resources.

Empirical data obtained from the questionnaire conducted near the end of the reform shows that the students interviewed for this study have gained greatly in the course of learning, displayed principally in the following three aspects (see Tables VI \& VII).

TABLE VI. OVERVIEW OF BENEFITS FROM PPT PREPARATION / PRESENTATION

\begin{tabular}{|c|c|c|c|}
\hline $\begin{array}{c}\text { Improve computer skills } \\
\text { \& abilities to make PPT }\end{array}$ & $\begin{array}{c}\text { Develop abilities to } \\
\text { search, screen and } \\
\text { synthesize literature }\end{array}$ & $\begin{array}{c}\text { Increase confidence in } \\
\text { English-learning via PPT oral } \\
\text { presentation }\end{array}$ & $\begin{array}{c}\text { Online resources, PPT- } \\
\text { preparation, lectures and class } \\
\text { interaction being helpful in deeper } \\
\text { understanding }\end{array}$ \\
$\begin{array}{c}\text { Learning other groups' PPT } \\
\text { and reflections being helpful in } \\
\text { consolidating what has been } \\
\text { learnt }\end{array}$ \\
\hline 4.1 & 4.0 & 4.0 & 4.0 \\
\hline
\end{tabular}


TABLE VII. SUMMARY OF LEARNING OUTCOMES FROM BLENDED LEARNING

\begin{tabular}{|c|c|c|c|c|}
\hline $\begin{array}{c}\text { Using rich online resources } \\
\text { beneficial to improving OE } \\
\text { communicative competence }\end{array}$ & $\begin{array}{c}\text { Like blended teaching } \\
\text { mode due to richer } \\
\text { resources \& knowledge }\end{array}$ & $\begin{array}{c}\text { The mixed learning mode } \\
\text { improved English thinking } \\
\text { and oral communicative } \\
\text { competence }\end{array}$ & $\begin{array}{c}\text { Blended learning model } \\
\text { improved autonomous } \\
\text { learning ability }\end{array}$ & $\begin{array}{c}\text { Blended learning model } \\
\text { improved time management } \\
\text { ability }\end{array}$ \\
\hline 4.1 & 4 & 3.8 & 3.6 & 3.6 \\
\hline
\end{tabular}

\section{DISCUSSION}

Information technology is changing people's lives and the way of education at an amazing pace. Reconstructing teaching against the background MOOCs has set higher demands on English teachers in terms of English linguistic knowledge, cultural knowledge and humanistic quality. Blended learning mode resulting from "Flipped Classroom" and Online teaching and such like is "student-centered", and learners can complete their learning tasks according to their own interests and personal levels. Through integration of classroom teaching and off-class practice, online and offline learning, traditional teaching materials and digital information, teaching can effectively stimulate students' learning motivation, develop their autonomous learning skills, and ultimately improve their abilities to make PPT presentation, and creative thinking and oral expressive and communicative competence. However, based on the present empirical study on OE2 teaching reform, this paper puts forward three points to be discussed as below:

1. The online course reform requires a large number of teaching resources covering audio and video clips. Teachers should try their best to collect adequate digital information and traditional teaching resources to enrich content and enhance students' interest in learning. Meanwhile, creating English learning environment cannot be ignored. The start of a weekly English radio station on campus is a good way to create a good learning atmosphere.

2. The course reform against MOOCs provides students with abundant resources with the characteristic of flexibility, that is, students can adjust their learning speed according to their own level and study at an appropriate time and place. However, this blended learning mode puts a high demand on students for autonomous learning. In this case, the teacher should focus on students' individuality and differences and show concern for those with a weak foundation and lacking autonomous learning skills. In other words, the reform and blended learning mode can change the phenomenon of teachers' "discourse hegemony" and students' "aphasia” in class, but it is a great challenge for teachers to keep students with insufficient learning ability in sync.

3. Teachers should bear in mind that network resources is not a substitute for face-to-face interaction or communication between teachers and students or imparting knowledge in class. In this light, English teachers should improve their own
English linguistic knowledge, cultural knowledge and humanistic quality so as to meet the challenge of teaching reconstruction against MOOCs successfully.

\section{CONCLUSION}

Taking 45 students in Jiangxi Police Institute as subject, this paper, through OE2, proves that classroom teaching reform is not only imperative but also conducive to improving the teaching effects. Based on the empirical data, it draws three conclusions: 1 . the classroom teaching reform has improved the students' abilities to make PPT, especially developed their abilities to search literature, to screen and to use network learning resources synthetically; 2. it has enhanced the students' confidence to speak up, thus improving their English expressive and oral communicative competence in the real sense, and 3. it has improved the students' autonomous learning capabilities and critical thinking and analytical and problem-solving abilities. In short, OE2 reform has improved the teaching effect and achieved the desired effects of "having vigor in class and motive after class”.

\section{REFERENCES}

[1] Krashen, S. P. Second Language Acquisition \& Second Language Learning, Oxford, Pergamon Press, 1981.

[2] Wang, J. "The Enlightenment of Second Language Acquisition Theory on Oral English Teaching”, Foreign Languages and their Teaching, 2006, 6: 30-32.

[3] Xue, H. "On Teacher-Student Interaction in Oral English Teaching”, Education Research Monthly, China, 2014, 1: 107-111.

[4] Xu, X. "Integration of Speech Skills in the Evaluation of Postgraduates' Oral English Test”, Oversea English, 2013, 1: 119-120.

[5] Xue, S. An Empirical Study of Using American Drama as Auxiliary Materials in Teaching Oral English at College, dissertation, 2016.

[6] Wang, G. "An Online Learning Platform for College Students". Advances in Social Science, Education and Humanities Research, 106: 226-229. Proceedings of the "2017 International Conference on Education Science and Economic Management”.

[7] Yang, L. "Practical Research on Blended Learning Based on WeChat Public Platform”. Advances in Social Science, Education and Humanities Research, 106: 37-40. Proceedings of the "2017 International Conference on Education Science and Economic Management”.

[8] Xue, H. "On Blended Learning and Oral English Communicative Competence-Taking 'Oral English 3' Online Course as an Example”. Proceedings of the "2018 2nd International Conference on Management, Education and Social Science”. 